\title{
Surface Wettability of Wood Species from Tropical and Temperafe Zones by Polar and Dispersive Liquids
}

\section{Kvašenje površine drva iz tropskih i umjerenih zona polarnim i disperzivnim tekućinama}

\author{
Original scientific paper • Izvorni znanstveni rad \\ Received-prispjelo: 20. 1. 2017. \\ Accepted-prihvaćeno: 1. 12. 2017. \\ UDK: $630 * 812.24$ \\ doi:10.5552/drind.2017.1704
}

\begin{abstract}
Wood species from Africa, South America and Europe, primarily used as a flooring and construction material, were acquired for the study. Wettability was determined using the measurement of the contact angle of wood with the reference liquids (water, diiodomethane) based on the sessile drop method. Surface free energy of wood on tangential sections within first $60 \mathrm{~s}$ after applying a drop was determined. Among the species from the tropical zone, the greatest hydrophobicity, similar to oak wood, was characteristic for courbaril wood. After $60 \mathrm{~s}$, the value of the surface free energy for the heartwood of the studied species was between 60 and $70 \mathrm{~mJ} \cdot \mathrm{m}^{-2}$, while for the sapwood of pine and birch, it was about $80 \mathrm{~mJ} \cdot \mathrm{m}^{-2}$. The biggest changes in the work of adhesion, within 60 $s$ after the application of a drop of water on the surface of the wood, was stated for pine sapwood, and the smallest one for tauari and courbaril wood.
\end{abstract}

Keywords: contact angle, diiodomethane, surface free energy, water, wettability

\begin{abstract}
SAŽETAK • Istraživanje je provedeno na vrstama drva rasprostranjenima u Africi, Južnoj Americi i Europi, ponajprije na onima koje se upotrebljavaju kao materijal za podove $i$ za gradnju. Kvašenje drva određeno je mjerenjem kontaktnog kuta drva s referentnim tekućinama (vodom, dijodometanom) postupkom kapanja. Utvrđena je površinska slobodna energija na tangencijalnom presjeku drva unutar prvih 60 s nakon nanošenja kapi. Među vrstama drva iz tropske zone najveću je hidrofobnost, sličnu onoj koju ima hrastovo drvo, pokazalo drvo jatobe. Vrijednost slobodne površinske energije za srževinu ispitivanih vrsta drva nakon $60 \mathrm{~s}$ bila je između 60 i $70 \mathrm{~mJ} \cdot \mathrm{m}^{-2}$, dok je za borovinu i brezovinu bila oko $80 \mathrm{~mJ} \cdot \mathrm{m}^{-2}$. Najveće promjene zbog djelovanja adhezije unutar 60 sod nanošenja kapljice vode na površinu drva zabilježene su za borovinu, a najmanje za drvo brazilskog hrasta i drvo jatobe.
\end{abstract}

Ključne riječi: kontaktni kut, dijodometan, slobodna površinska energija, voda, kvašenje

\footnotetext{
${ }^{1}$ Authors are assistant professor and associate professor at Faculty of Wood Technology, Warsaw University of Life Sciences - SGGW, Warsaw, Poland.

${ }^{1}$ Autori su docentica i izvanredni profesor Fakulteta drvne tehnologije, Varšavsko sveučilište bioloških znanosti - SGGW, Varšava, Poljska.
} 


\section{INTRODUCTION}

\section{UVOD}

Wood, as an organic material, is built of carbohydrates (ca. $70 \%$ ), i.e. cellulose and hemicelluloses, which are compounds with a relatively large quantity of polar hydroxyl groups -OH in their structure (Požgaj et al., 1993; Gindl et al., 2004). For that reason, wood shows high affinity for water. This property of wood is described by a number of parameters including adsorption, desorption, swelling, water absorption, wettability expressed by the measurement of the contact angle (Mantanis et al., 1994; Wolkenhauer et al., 2009; Buyuksari et al., 2011; Dündar et al., 2012; Hill et al., 2012).

An important variable that allows the determination of the ability of wood to interact with liquids is the measurement of the wettability expressed through the contact angles for different types of reference liquids (De Meijer et al., 2000; Gindl et al., 2001; Wolkenhauer et al., 2009). The difficulties associated with it result from the fact that wood, as porous material, varies in terms of morphological and chemical structure, having different properties within and between species. Studies carried out so far (Zhang et al., 1997; Kúdela, 2014; Rolleri et al., 2016) show that the wettability of wood shows a significant differentiation depending on the chemical composition, roughness, polarity of the wetting liquid, processing method and air parameters. Wood wettability is also significantly affected by thermal treatment (Gérardin et al., 2007; Kocaefe et al., 2008) or fungicide protection, among others (Fuczek et al., 2010).

Liptáková and Kúdela (1994) and Kúdela (2014) determined the contact angle after the separation of a drop of liquid from the needle $(\mathrm{t}=0 \mathrm{~s})$ and in the equilibrium state at the phase boundary wood-liquid. Huang et al. (2012) varied the time of determining the contact angle of jack pine wood (Pinus banksiana Lamb.) depending on the type of the reference liquid. Authors studied the contact angle of wood with water for $50 \mathrm{~s}$, with ethylene glycol for $10 \mathrm{~s}$ and with formamide for $1 \mathrm{~s}$, while maintaining the appropriate in- tervals between the measurements. Santoni and Pizzo (2011) studied the contact angle of Mediterranean wood species with water at intervals of $0.3 \mathrm{~s}$ for $150 \mathrm{~s}$. Kocaefe et al. (2008) marked the contact angle of white ash (Fraxinus americana) and soft maple (Acer rubrum) before and after heat treatment within $30 \mathrm{~s}$. Due to the dynamics of changes, the more rational solution is to define the contact angle of wood with water for a specified period of time. This makes it possible to determine more complete wettability characteristics of wood. Wettability of wood is described by a number of parameters, of which the most studied and analysed are contact angle and surface free energy. Only a few authors examine wetting energy, spreading coefficient of reference liquid, work of adhesion for the phase boundary wood-liquid, surface tension of the liquid (Zhang et al., 1997; Kocaefe et al., 2008; Wolkenhauer et al., 2009; Gonzalez de Cademartori et al., 2015).

The aim of this study was to determine the wettability of wood species from Africa, South America and Europe used mainly as flooring and construction materials. Important aspect of the study was to determine the dynamics of changes in parameters describing the phenomenon of wood wettability.

\section{MATERIALS AND METHODS} 2. MATERIJALI I METODE

Wood species selected for the study are used to manufacture flooring materials and construction elements according to EN 1912:2012+AC (2013). Table 1 summarizes the basic information about the studied species of wood. Surfaces of wood samples were finished by planing. After conditioning the samples to an air-dry condition in accordance with the recommendations of ISO 13061-1 (2014), wood density was determined using a stereometric method in accordance with the requirements of ISO 13061-2 (2014). Wood moisture content was determined according to ISO 13061-1 (2014).

Contact angles of wood with reference liquids were studied in a goniometer Phoenix 300 of Surface

Table 1 Investigated species of wood

Tablica 1. Istraživane vrste drva

\begin{tabular}{|c|c|c|c|}
\hline $\begin{array}{l}\text { Latin name } \\
\text { Latinski naziv }\end{array}$ & $\begin{array}{c}\text { Trade name of wood (and code) } \\
\text { according to EN-13556 (2003) } \\
\text { Trgovački naziv ( } i \text { kôd) prema } \\
\text { EN-13556 (2003) }\end{array}$ & $\begin{array}{c}\text { Occurrence } \\
\text { Podrijetlo vrste }\end{array}$ & $\begin{array}{l}\text { Structure } \\
\text { of wood } \\
\text { Građa drva }\end{array}$ \\
\hline Afzelia africana Smith ex. Pers. & afzelia (AFXX) / afzelija & Africa / Afrika & \multirow{5}{*}{$\begin{array}{l}\text { deciduous } \\
\text { listača } \\
\text { diffuse-porous } \\
\text { difuzno porozno drvo }\end{array}$} \\
\hline Betula pendula Roth & $\begin{array}{l}\text { European birch (BTXX) } \\
\text { obična breza }\end{array}$ & Europe / Europa & \\
\hline Couratari multiflora (J.E. Smith) Eyma & tauari (CIXX) / brazilski hrast & $\begin{array}{l}\text { South America } \\
\text { Južna Amerika }\end{array}$ & \\
\hline Hymenea courbaril $\mathrm{L}$. & courbaril (HYCB) / jatoba & $\begin{array}{l}\text { South America } \\
\text { Južna Amerika }\end{array}$ & \\
\hline Khaya ivorensis A. Chev. & $\begin{array}{l}\text { African mahogany (KHXX) } \\
\text { afrički mahagonij }\end{array}$ & Africa / Afrika & \\
\hline Pinus sylvestris $\mathrm{L}$. & Scots pine (PNSY) / obični bor & Europe / Europa & $\begin{array}{l}\text { coniferous / četinjača } \\
\text { sapwood / bjeljika }\end{array}$ \\
\hline Quercus robur $\mathrm{L}$. & $\begin{array}{l}\text { European oak (QCXE) } \\
\text { hrast lužnjak }\end{array}$ & Europe / Europa & $\begin{array}{l}\text { deciduous / listača } \\
\text { ring-porous } \\
\text { prstenasto porozno drvo }\end{array}$ \\
\hline
\end{tabular}


Table 2 Surface tension components of reference liquids (Gindl et al., 2001)

Tablica 2. Komponente površinske napetosti referentnih tekućina (Gindl et al., 2001.)

\begin{tabular}{|l|c|c|c|}
\hline \multirow{2}{*}{\begin{tabular}{c}
\multirow{2}{*}{$\begin{array}{c}\text { Liquid } \\
\text { Tekućina }\end{array}$} \\
\cline { 2 - 4 }
\end{tabular}} & $\begin{array}{c}\text { Surface tension / Površinska napetost } \\
\mathrm{mJ} \cdot \mathrm{m}^{-2}\end{array}$ & $\begin{array}{c}\text { Dispersive / Disperzivnost } \\
\mathrm{mJ} \cdot \mathrm{m}^{-2}\end{array}$ & $\begin{array}{c}\text { Polar / Polarnost } \\
\mathrm{mJ} \cdot \mathrm{m}^{-2}\end{array}$ \\
\hline $\begin{array}{l}\text { water }\left(\mathrm{H}_{2} \mathrm{O}\right) / \text { voda } \\
\text { diiodomethane }\left(\mathrm{CH}_{2} \mathrm{I}_{2}\right)\end{array}$ & 72.80 & 21.90 & 51.00 \\
\hline dijodometan & 50.80 & 50.80 & 0.00 \\
\hline
\end{tabular}

Electro Optics company (Suwon City, Korea), based on a "sessile" drop method. The volume of the drop applied to the surface of wood (tangential section) was $3 \mu 1$. Two reference liquids were used for the study: water and diiodomethane (Table 2).

Based on the conducted studies, work of adhesion for the phase boundary wood-water was determined. Surface free energy of wood species selected for the study was determined using the Owens-Wendt method (Owens and Wendt, 1969) based on Young's equation:

$$
\sigma_{\mathrm{S}}=\gamma_{\mathrm{SL}}+\sigma_{\mathrm{L}} \cdot \cos \theta
$$

where: $\sigma_{\mathrm{S}}$ is the total surface free energy of the solid $\left(\mathrm{mJ} \cdot \mathrm{m}^{-2}\right), \gamma_{\mathrm{SL}}$ is the interfacial tension between solid and liquid, $\sigma_{\mathrm{L}}$ is the surface tension of the liquid, and $\theta$ is the contact angle $\left(^{\circ}\right)$.

The total surface energy $\left(\sigma_{\mathrm{S}}\right)$ is divided into a dispersive part $\left(\sigma^{\mathrm{D}}\right)$ and a polar part $\left(\sigma^{\mathrm{P}}\right)$ according to the equation:

$$
\sigma_{\mathrm{S}}=\sigma^{\mathrm{D}}+\sigma^{\mathrm{P}}
$$

The interfacial tension between solid and liquid is described by the equation:

$$
\gamma_{\mathrm{SL}}=\sigma_{\mathrm{S}}+\sigma_{\mathrm{L}}-2 \cdot\left(\sqrt{\sigma_{\mathrm{S}}^{\mathrm{D}} \cdot \sigma_{\mathrm{L}}^{\mathrm{D}}}+\sqrt{\sigma_{\mathrm{S}}^{\mathrm{P}} \cdot \sigma_{\mathrm{L}}^{\mathrm{P}}}\right)
$$

where: $\sigma_{L}^{D}$ and $\sigma_{\mathrm{L}}^{\mathrm{P}}$ are dispersive and polar parts of liquid, respectively; $\sigma_{S}^{D}$ and $\sigma_{S}^{P}$ are dispersive and polar parts of solid, respectively. equation:

The work of adhesion $\left(W_{\mathrm{SL}}\right)$ is determined by the

$$
W_{\mathrm{SL}}=\sigma_{\mathrm{S}}+\sigma_{\mathrm{L}}-\gamma_{\mathrm{SL}}
$$

In order to obtain an optimal adhesion, the work of adhesion must achieve the maximum value. This occurs when the interfacial tension $\left(\gamma_{\mathrm{SL}}\right)$ is 0 . Good adhesion is obtained if the dispersive and polar parts of the solid and liquid phases are in the right ratio, because only dispersive - dispersive and polar - polar interactions occur (Wolkenhauer et al., 2009). Therefore, the work of adhesion can be divided into a dispersive and a polar part according to the equation:

$$
W_{\mathrm{SL}}=W_{\mathrm{SL}}^{\mathrm{D}}+W_{\mathrm{SL}}^{\mathrm{P}}
$$

where:

$$
\begin{aligned}
& W_{\mathrm{SL}}^{\mathrm{D}}=2 \sqrt{\sigma_{\mathrm{L}}^{\mathrm{D}} \cdot \sigma_{\mathrm{S}}^{\mathrm{D}}} \\
& W_{\mathrm{SL}}^{\mathrm{P}}=2 \sqrt{\sigma_{\mathrm{L}}^{\mathrm{P}} \cdot \sigma_{\mathrm{S}}^{\mathrm{P}}}
\end{aligned}
$$

Values of the contact angle were determined 1, 2, $3,10,20,30,40,50$ and $60 \mathrm{~s}$ after the application of a liquid drop on the surface of the wood and by extrapo- lating within 0 s. Surface free energy of investigated wood species and components of the surface free energy - polar, dispersive, work of adhesion were determined after $60 \mathrm{~s}$. Studies were performed after $24 \mathrm{~h}$ from the sample preparation. Statistical analysis was performed using STATISTICA version-12 software of StatSoft, Inc. Statistical analysis of the test results was carried out at the significance level of 0.050 . For other studied parameters, trend lines were determined, and the parameters for the equation of the curve $(y)$ and the coefficients of determination $R^{2}$ were provided.

\section{RESULTS AND DISCUSSION 3. REZULTATI I RASPRAVA}

According to ISO 13061-2 (2014), the density of wood from the tropical zone was as follows: African mahogany $562 \mathrm{~kg} \cdot \mathrm{m}^{-3}( \pm 24)$, afzelia $717 \mathrm{~kg} \cdot \mathrm{m}^{-3}( \pm 21)$, courbaril $847 \mathrm{~kg} \cdot \mathrm{m}^{-3}( \pm 5)$, tauari $844 \mathrm{~kg} \cdot \mathrm{m}^{-3}( \pm 16)$, and the density of wood from the temperate zone was as follows: European birch $635 \mathrm{~kg} \cdot \mathrm{m}^{-3}( \pm 21)$, Scots pine (sapwood) $495 \mathrm{~kg} \cdot \mathrm{m}^{-3}( \pm 9)$, European oak (heartwood) $758 \mathrm{~kg} \cdot \mathrm{m}^{-3}( \pm 84)$. The wood moisture content ranged from $6.53 \%( \pm 0.12)$ to $6.82 \%( \pm 0.25)$ in case of all tested wood species. The density of the tested wood species was typical, showing at the same time the typical variability of the property. For example, according to the study of Sekhar and Negi (1960), carried out on 250 logs from 50 different wood species, density variation coefficient within a single species of wood in an air-dry condition averaged to about $6 \%$. In the standard ISO 3129 (1979), an average value of $10 \%$ was assumed for a typical variation coefficient of wood density.

A statistically significant correlation was established between density and contact angle for woodwater relations and between density and contact angle for wood-diiodomethane relations $(p=0.00001)$. However, if we tried to describe these relationships by the linear regression model, the values of the coefficient of determination would be low. The $R^{2}$ value for the relationship between density and contact angle for woodwater was 0.517 , and for the relationship between density and contact angle for wood-diiodomethane, it was 0.394 (Figure 1).

The difference between the wettability of softwood (Scots pine) and hardwood (African mahogany, afzelia, birch, courbaril, European oak, tauari) species was demonstrated. This difference was statistically significant (Table 3 ). The variability of contact angle is most likely the result of different anatomical structure and chemical composition (non-structural compounds 


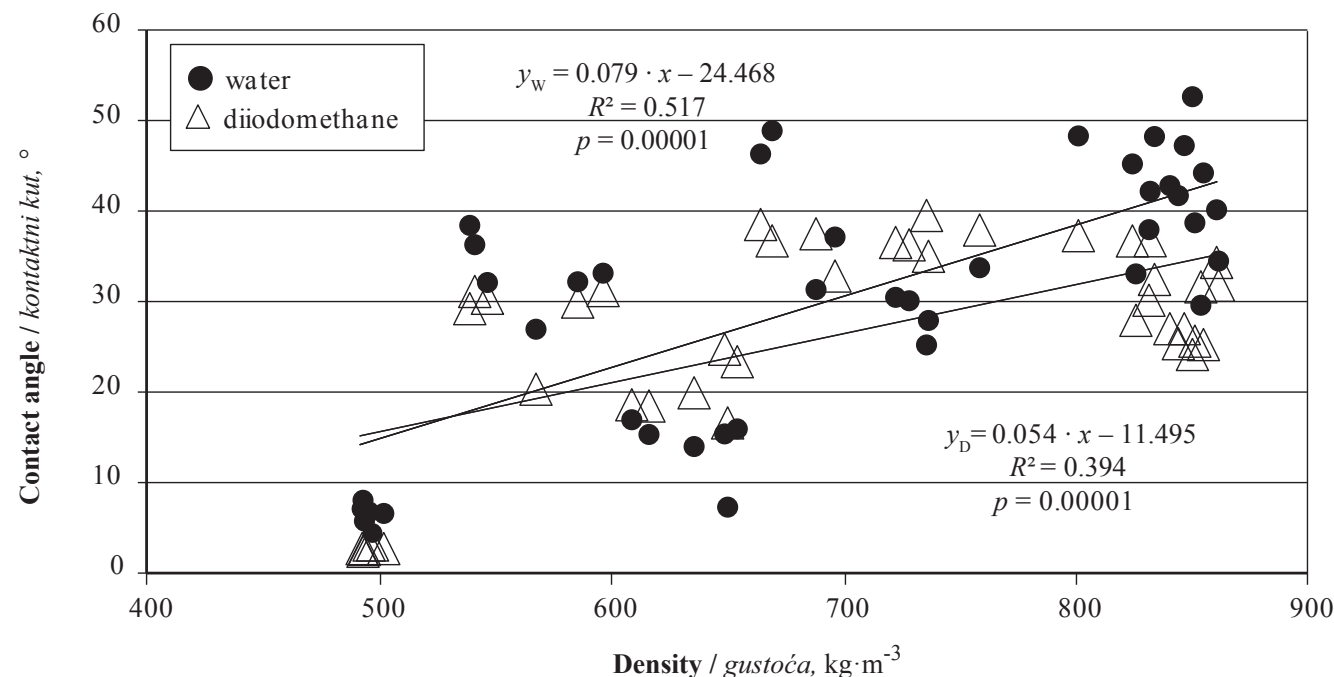

Figure 1 Relationship between density and contact angle determined $60 \mathrm{~s}$ after application of a liquid drop on wood surface Slika 1. Odnos između gustoće i kontaktnoga kuta određen 60 s nakon nanošenja kapi tekućine na površinu drva

Table 3 Results of statistical analysis ( $\mathrm{t}$ - test) for contact angle and surface free energy determined $60 \mathrm{~s}$ after application of a liquid drop on wood surface

Tablica 3. Rezultati statističke analize ( $t$-test) za kontaktni kut i slobodnu površinsku energiju utvrđeni $60 \mathrm{~s}$ nakon nanošenja kapi tekućine na površinu drva

\begin{tabular}{|c|c|c|c|c|c|c|}
\hline \multirow{4}{*}{$\begin{array}{l}\text { Wood species } \\
\text { Vrsta drva }\end{array}$} & \multicolumn{4}{|c|}{ Contact angle / Kontaktni kut } & \multicolumn{2}{|c|}{$\begin{array}{c}\text { Surface free energy } \\
\text { Slobodna površinska energija }\end{array}$} \\
\hline & \multicolumn{2}{|c|}{$\begin{array}{l}\text { wood - water } \\
\text { Drvo - voda }\end{array}$} & \multicolumn{2}{|c|}{$\begin{array}{l}\text { wood - diiodomethane } \\
\text { Drvo - dijodometan }\end{array}$} & & \\
\hline & \multicolumn{6}{|c|}{ Statistical measures } \\
\hline & $t$ & $p$ & $t$ & $p$ & $t$ & $p$ \\
\hline $\begin{array}{l}\text { softwood vs. hardwood } \\
\text { drvo četinjača vs. drvo listača }\end{array}$ & -4.384760 & 0.000097 & -10.099300 & 0.000000 & 3.634960 & 0.008343 \\
\hline \multicolumn{7}{|l|}{ Wood area / dio drva } \\
\hline $\begin{array}{l}\text { sapwood vs. heartwood } \\
\text { bjeljika vs. srževina }\end{array}$ & -11.825300 & 0.000000 & -9.151830 & 0.000000 & 7.778898 & 0.000109 \\
\hline
\end{tabular}

content), different surface structure and thus different roughness of particular wood species (Liptáková et al., 1995; Wolkenhauer et al., 2009). The value of the contact angle depends primarily on whether it takes place through the heartwood (African mahogany, afzelia, courbaril, European oak, tauari) or sapwood (birch and pine) (Table 3). This was due to the fact that sapwood has an open structure for conducting water. In the cell walls of sapwood, the pits are open. Furthermore, the increased wettability of this area is determined by the presence of living unlignified parenchyma cells of wood and wood rays. The results obtained for pine sapwood and heartwood of hardwood species were confirmed in previous research. Santoni and Pizzo (2011),
- Africanmahogany $\Delta$ afzelia $\times$ tauari $*$ courbaril

- European birch $\circ$ European oak $\square$ Scotspine

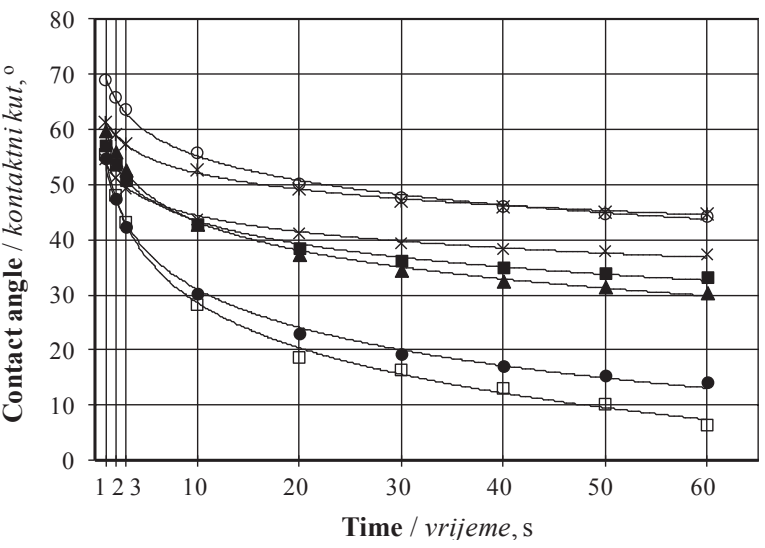

a)

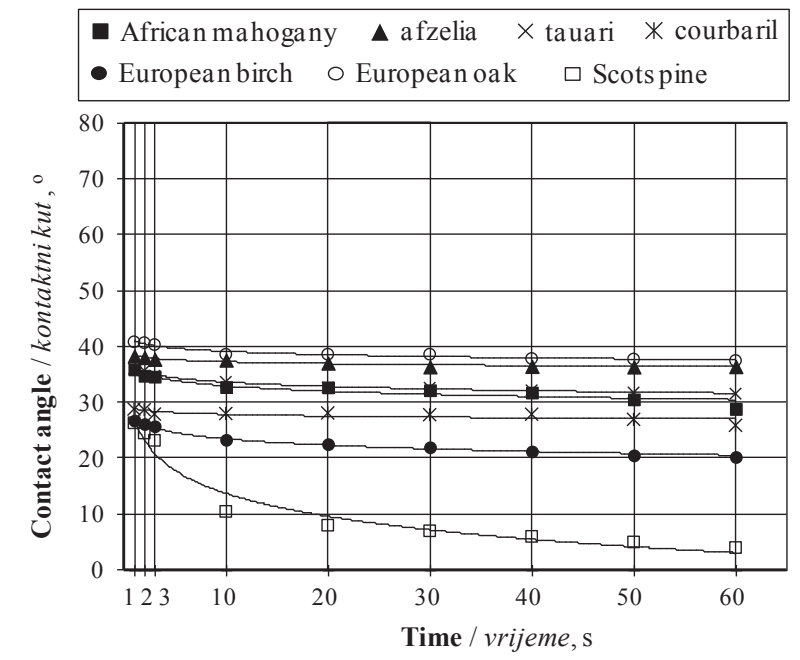

b)

Figure 2 Contact angles at phase boundary wood-water (a), wood-diiodomethane (b)

Slika 2. Kontaktni kutovi na granici drva i vode (a), drva i dijodometana (b) 
Table 4 Parameters of curve equation $y=a \cdot \ln (t)+(b)$ describing the changes of contact angle for phase boundary woodwater, wood-diiodomethane ( $a$ - direction coefficient, $b$ - free term, $R^{2}$ - coefficient of determination, $t$ - time)

Tablica 4. Parametri jednadžbe krivulje $y=a \cdot \ln (t)+(b)$ koja opisuje promjene kontaktnog kuta na granici drva i vode te drva i dijodometana ( $a$ - koeficijent smjera, $b$ - odsječak na osi $y, R^{2}$ - koeficijent determinacije, $t$ - vrijeme)

\begin{tabular}{|c|c|c|c|c|c|c|}
\hline \multirow{3}{*}{$\begin{array}{c}\text { Wood species } \\
\text { Vrsta drva }\end{array}$} & \multicolumn{6}{|c|}{$\begin{array}{l}\text { Parameters of curve equation } \mathbf{y}=\boldsymbol{a} \cdot \ln (\boldsymbol{t})+\boldsymbol{b} \\
\text { Parametri jednadžbe krivulje } y=a \cdot \ln (t)+b\end{array}$} \\
\hline & \multicolumn{3}{|c|}{$\begin{array}{c}\text { Contact angle } \\
\text { wood-water } \\
\text { Kontaktni kut drvo - voda }\end{array}$} & \multicolumn{3}{|c|}{$\begin{array}{c}\text { Contact angle } \\
\text { wood-diiodomethane } \\
\text { Kontaktni kut drvo - dijodometan }\end{array}$} \\
\hline & $a$ & $b$ & $R^{2}$ & $a$ & $b$ & $R^{2}$ \\
\hline African mahogany / afrički mahagonij & -6.04 & 57.34 & 0.997 & -1.36 & 36.05 & 0.883 \\
\hline Afzelia / afzelija & -7.48 & 60.48 & 0.998 & -0.50 & 38.40 & 0.944 \\
\hline Tauari / brazilski hrast & -4.24 & 54.16 & 0.996 & -1.10 & 36.13 & 0.990 \\
\hline Courbaril / jatoba & -4.24 & 61.86 & 0.997 & -0.45 & 28.86 & 0.590 \\
\hline European birch / obična breza & -10.01 & 54.08 & 0.997 & -1.62 & 27.17 & 0.987 \\
\hline European oak / hrast lužnjak & -6.40 & 69.93 & 0.996 & -0.84 & 41.02 & 0.955 \\
\hline Scots pine / obični bor & -11.84 & 55.86 & 0.998 & -5.93 & 27.34 & 0.966 \\
\hline
\end{tabular}

who examined the Mediterranean species of wood, stated that in general softwoods showed higher contact angles than hardwoods due to different anatomy and presence of resins and terpenes in addition to fatty acids and phenolic components, also presents in hardwoods.

The surface of pine sapwood was the most hydrophilic among all studied wood species. Comparable changes of the contact angle of wood with water were reported for birch wood (Figure 2a). Within the conducted studies, the contact angle of pine and birch, $3 \mathrm{~s}$ after the application of a drop of water on the wood surface, was $46.25^{\circ}( \pm 6.22)$ and $42.44^{\circ}( \pm 3.58)$, respectively, and after $60 \mathrm{~s}, 6.45^{\circ}( \pm 1.83)$ and $14.29^{\circ}( \pm 3.91)$, respectively. The presented data show that, over time, the hydrophobicity of pine sapwood decreased significantly and was lower than in case of birch wood. Pine sapwood was characterized by considerably lower density, i.e. higher porosity $(67 \%)$ than other wood species under research (from 44 to $62 \%$ ). The process of water and diiodomethane penetration into the porous structure of pine sapwood was quicker than into other wood species tested. This resulted in the biggest changes in contact angle in time. Bekhta et al. (2015) stated that pine wood was the most hydrophobic among the studied wood species (pine, alder, beech, birch). The authors state that the contact angle of the pine and birch wood, $5 \mathrm{~s}$ after applying a drop of water on the wood surface, was $54.19^{\circ}$ and $45.34^{\circ}$, respectively. These differences may be due to, among others, the type of the studied wood (pine sapwood or heartwood) and the resin content in the wood, which is a component significantly affecting wood hydrophobicity (Fengel and Wegener, 1989). Kúdela (2014) stated that the contact angle for the phase boundary beech-water at the beginning of the wetting process $(\mathrm{t}=0 \mathrm{~s})$ was $63.9^{\circ}$, while the contact angle at the time necessary to reach the equilibrium state at the phase boundary wood-water (at the moment when the drop started to contract) was $20.8^{\circ}$.

The surface of oak wood was the most hydrophobic one. The contact angle of oak wood, $60 \mathrm{~s}$ after the application of a drop of water on the wood surface, was $44.28^{\circ}( \pm 5.63)$. It is worth noting that the contact angle of European oak with the ring-porous structure was higher than the contact angle of tropical species i.e. afzelia, tauari, courbaril with diffuse-porous structure. Among the species from the tropical zone, the greatest hydrophobicity, similar to oak wood, was characteristic for courbaril wood. These interdependencies are mainly due to the fact that, generally, the species from the tropical zone have a much larger diameter of vessels compared to species of the temperate zone (Wagenführ, 2007).

Contact angles with a polar liquid (water) significantly changed over time. The dynamics of changes of the contact angle was significantly greater in the case of wetting wood with water than with diiodomethane (Figure $2 \mathrm{a}, \mathrm{b}$ ). Contact angles of wood with water were the highest at the time of the drop application (at $0 \mathrm{~s}$ time of $70^{\circ}$ ), and then within $60 \mathrm{~s}$ decreased logarithmically (curve equations presented in Table 4). In case of heartwood, the dynamics of changes was lower and the terminal value of the angle ( $60 \mathrm{~s}$ after applying a drop) ranged from 35 to $40^{\circ}$. In case of sapwood, the terminal values of contact angle were only about $10^{\circ}$. In case of a nonpolar liquid (diiodomethane), the angles changed to a lesser extent. The initial values of contact angles of the tested wood species were in the range from about $30^{\circ}$ to $40^{\circ}$. The biggest changes of the contact angle were noted for pine sapwood, for which the contact angle with diiodomethane, $60 \mathrm{~s}$ after applying a drop, was only about $5^{\circ}$ (change at the level of $85 \%$ ). In case of European birch and African mahogany, the changes of the contact angle within $60 \mathrm{~s}$ were about $20 \%$. For the remaining species of wood, comparable changes of the contact angle with diiodomethane were observed. Within $60 \mathrm{~s}$ after applying a drop of liquid on the surface of the wood, the contact angle decreased by about $10 \%$. Gérardin et al. (2007), who studied the contact wetting angle based on the Wilhelmy method (based on the procedure indicated in Gardner et al., 1991; Wålinder and Johansson, 2001; Wålinder and Ström, 2001; Pétrissans et al., 2003), obtained the contact angle for water-pine sapwood at $55.4^{\circ}$, and for the diiodomethane-pine sapwood at $27.1^{\circ}$. The studies carried out by the authors, despite the implementation of different testing method for determining the contact angle of wood, confirm the dif- 


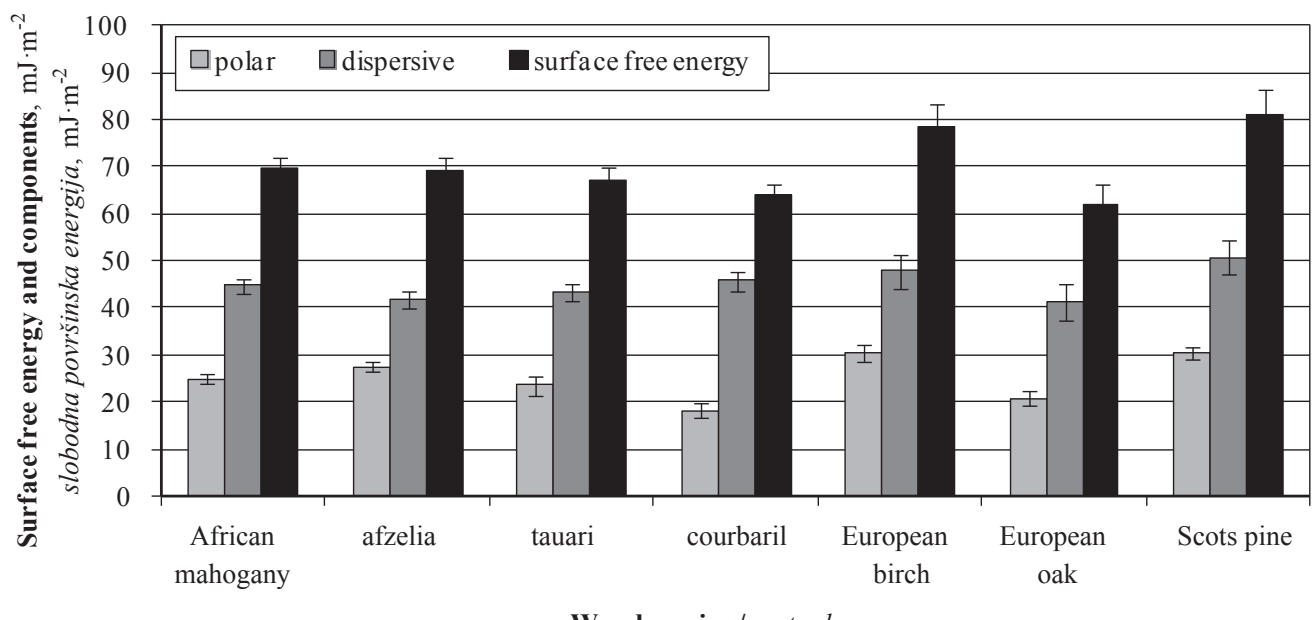

Wood species / vrsta drva

Figure 3 Surface free energy of investigated wood species and components of surface free energy - polar, dispersive Slika 3. Slobodna površinska energija istraživanih vrsta drva i komponente slobodne površinske energije - polarna i disperzivna

ferences in the wettability of pine wood with polar and dispersive liquids, obtained in this work.

Surface free energy of wood was also dependent on wood species and, above all, on whether it was sapwood or heartwood (Table 3). After $60 \mathrm{~s}$, the value of surface free energy for heartwood of the studied species was in the range of 60 to $70 \mathrm{~mJ} \cdot \mathrm{m}^{-2}$, while for pine and birch sapwood, it was about $80 \mathrm{~mJ} \cdot \mathrm{m}^{-2}$ (Figure 3). The dispersive component was the dominant component of the surface free energy. This is a typical feature characteristic for polymers of which the wood is composed (Mohan et al., 2011; Shen et al., 1998). According to $\mathrm{Li}$ et al. (2014), the high value of the dispersive component is the result of high interaction ability of the dispersive part of available carbon-oxygen and carbon-carbon bonds within the wood. On the other hand, the polar component refers to the interaction between hydroxyl groups of wood and functional groups of adhesive by forming the hydrogen bond. The research carried out in the field of surface free energy is confirmed by literature data. Kúdela (2014) stated that the surface free energy of beech wood, determined

Table 5 Results of statistical analysis ( $t$-test) for work of adhesion determined $60 \mathrm{~s}$ after application of a liquid drop on wood surface

Tablica 5. Rezultati statističke analize ( $t$-test) za adhezijski rad određen $60 \mathrm{~s}$ nakon nanošenja kapi tekućine na površinu drva

\begin{tabular}{|l|c|c|}
\hline \multirow{2}{*}{$\begin{array}{l}\text { Wood species } \\
\text { Vrsta drva }\end{array}$} & \multicolumn{2}{|c|}{$\begin{array}{c}\text { Work of adhesion } \\
\text { Adhezijski rad }\end{array}$} \\
\cline { 2 - 3 } & \multicolumn{2}{|c|}{$\begin{array}{c}\text { Statistical measures } \\
\text { Statisticke mjere }\end{array}$} \\
\cline { 2 - 3 } & $t$ & $p$ \\
\hline $\begin{array}{l}\text { African mahogany } \\
\text { afrički mahagonij }\end{array}$ & -2.0059 & 0.072670 \\
\hline Afzelia / afzelija & 2.9958 & 0.013439 \\
\hline Tauari / brazilski hrast & -2.0194 & 0.071049 \\
\hline Courbaril / jatoba & -7.5945 & 0.000019 \\
\hline European birch / obična breza & 2.8456 & 0.019226 \\
\hline European oak / hrast lužnjak & -3.0288 & 0.012703 \\
\hline Scots pine / obični bor & 1.9063 & 0.098288 \\
\hline
\end{tabular}

based on the study of the contact angles of wood wetted with water and $\alpha$-bromonaphthalene, was 84.7 $\mathrm{mJ} \cdot \mathrm{m}^{-2}$. Gérardin et al. (2007) stated that the total surface free energy (calculated based on the examination of the contact angle of wood with three reference liquids i.e. water, diiodomethane, formamide) obtained for untreated pine sapwood and beech was relatively close. The authors stated that the surface free energy of pine sapwood and beech was $58.6 \mathrm{~mJ} \cdot \mathrm{m}^{-2}$ and 54.8 $\mathrm{mJ} \cdot \mathrm{m}^{-2}$, respectively.

Statistically significant differences were identified in the work of adhesion for wood-water and wooddiiodomethane phase boundaries (Table 5). Exceptions were African mahogany, tauari and pine wood $(\mathrm{p}>$ $0.05)$. The average work of adhesion values for woodwater phase boundaries for tropical zone wood species ranged from 124 to $135 \mathrm{mN} \cdot \mathrm{m}^{-1}$ (Figure 4). The work of adhesion value observed for oak wood was similar $\left(125 \mathrm{mN} \cdot \mathrm{m}^{-1}\right)$, whereas the average work of adhesion value for birch and pine wood amounted to 143 and $145 \mathrm{mN} \cdot \mathrm{m}^{-1}$, respectively. Similar dependencies were noted in investigating the work of adhesion for wooddiiodomethane phase boundaries. In this case, the work of adhesion values, observed for oak wood, was likewise comparable to those of the tropical zone wood species. Li et al. (2014) stated that low values of the work of adhesion may be attributed to the air trapped in the rough and porous structure of the wood surface, which can decrease the wood-liquid contact area. Investigated wood species from tropical zone have large vessels, with average diameter above $150 \mu \mathrm{m}$, but without thyloses (Richter and Dallwitz, 2000). Oak wood has large diameter vessels as well (average diameter $160 \mu \mathrm{m}$ ), but only in earlywood, and they are filled with thyloses (Wagenführ, 2007), which mechanically block the penetration of water.

Investigated hygroscopic properties of wood largely depend on changes due to chemical and mechanical processes occurring in the wood structure in the process of creating heartwood. Mechanical closing of pits, presence of thyloses and over saturation with non-structural compounds affect the reduction of sur- 


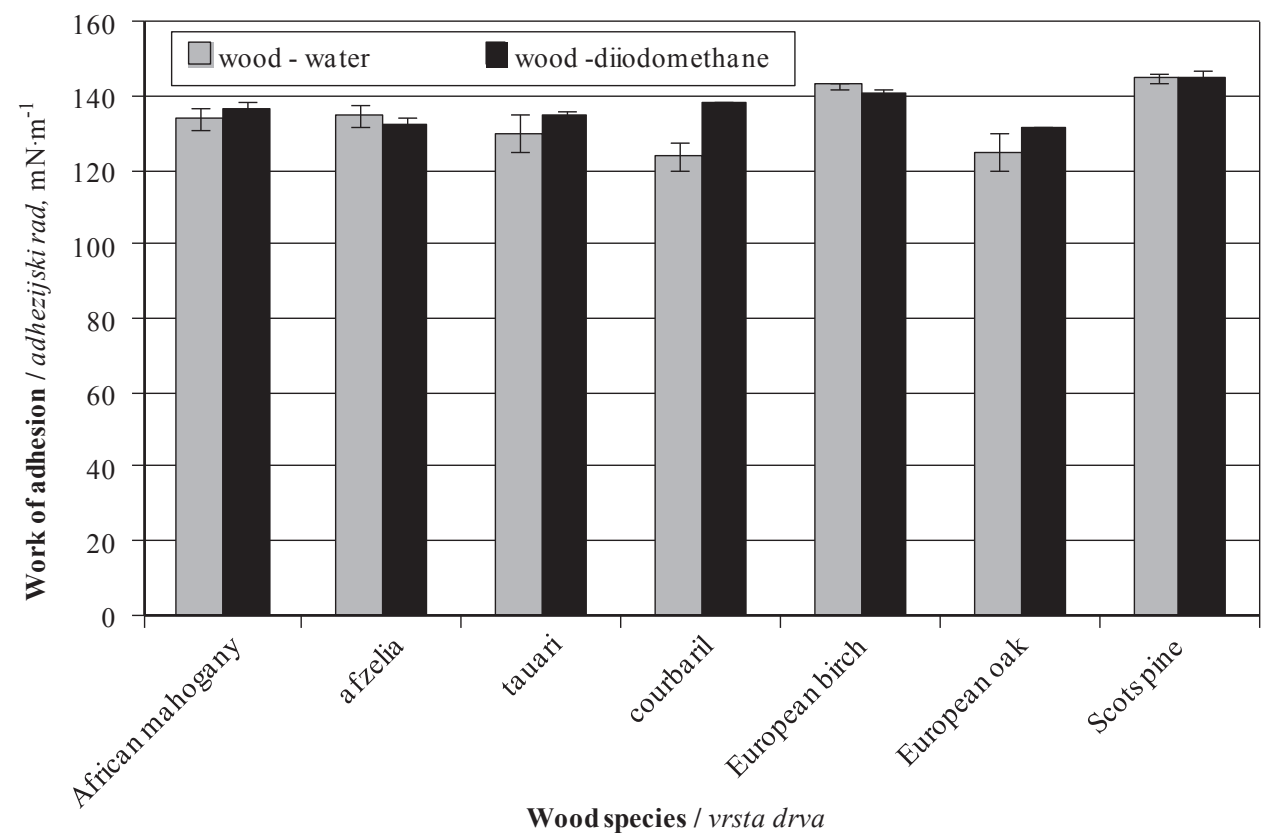

Figure 4 Work of adhesion for phase boundary wood-water and wood-diiodomethane Slika 4. Adhezijski rad za granicu drvo - voda i drvo - dijodometan

face wettability and wood absorptivity. The result of this was the high value of contact angles for European oak and courbaril, and a low one for the sapwood of pine and birch. The essential relationship between wood wettability and surface chemical composition as well as surface morphology was noticed by, among others, Shen et al. (1998) and Li et al. (2014). The results of the research have shown that, among the tested wood species, oak wood was characterized by the lowest susceptibility to wetting with polar and dispersive liquids, expressed by the highest contact angle values. Among the wood species from tropical zones, courbaril wood showed the lowest polar liquid wetting susceptibility, whereas afzelia wood had the lowest dispersive liquid wetting susceptibility. In view of the above, these wood species ought to be regarded as particularly suitable for use as flooring material.

\section{CONCLUSIONS}

4. ZAKLJUČAK

The biggest changes of contact angles in the case of polar liquid (water) were recorded for pine and birch sapwood (changes at the level of $24-84 \%$ during 60 $\mathrm{s})$. In the case of dispersive liquid (diiodomethane) for the first $60 \mathrm{~s}$ after applying a drop, the angles changed in a much smaller range (changes at the level of $3-10$ $\%$ ). Wettability of oak wood with ring-porous structure was lower than wettability of tropical wood species with diffuse-porous structure. Surface free energy of wood depended on the wood species and, above all, on whether it was heartwood or sapwood. After $60 \mathrm{~s}$, the value of the surface free energy for the heartwood of tested species was in the range of 60 to $70 \mathrm{~mJ} \cdot \mathrm{m}^{-2}$, while for the sapwood of pine and birch, it was about $80 \mathrm{~mJ} \cdot \mathrm{m}^{-2}$. The biggest changes of the work of adhesion, within $60 \mathrm{~s}$ after applying a drop of water on the wood surface, was recorded for pine sapwood (increase of $28 \%$ ) and the smallest one (increase of $15 \%$ ) for tauari and courbaril wood.

\section{REFERENCES}

5. LITERATURA

1. Bekhta, P.; Proszyk, S.; Krystofiak, T.; Lis, B., 2015: Surface wettability of short-term thermo-mechanically densified wood veneers. European Journal of Wood and Wood Products, 73 (3): 415-417.

https://doi.org/10.1007/s00107-015-0902-4

2. Buyuksari, U.; Akbulut, T.; Guler, C.; As, N., 2011: Wettability and surface roughness of natural and plantationgrown narrow-leaved ash (Fraxinus angustifolia Vahl.) wood. BioResources, 6 (4): 4721-4730.

3. De Meijer, M.; Haemers, S.; Cobben, W.; Militz, H., 2000: Surface energy determinations of wood: comparison of methods and wood species. Langmuir, 16 (24): 9352-9359. https://doi.org/10.1021/la001080n

4. Dündar, T.; Büyüksar, Ü.; Avc1, E.; Akkılıç, H., 2012: Effect of heat treament on the physical and mechanical properties of compression and opposite wood of black pine. BioResources, 7 (4): 5009-5018. https://doi.org/10.15376/biores.7.4.5009-5018

5. Fengel, D.; Wegener, G., 1989: Wood: Chemistry, Ultrastructure, Reactions. Berlin: Walter de Gruyter.

6. Fuczek, D.; Zabielska-Matejuk, J.; Pernak, J.; Przybylska, W., 2010: Wettability of wood surfaces treated with ionic liquids. Wood. Research Papers. Reports. Announcements 53 (184): 45-53.

7. Gardner, D. J.; Generella, N. C.; Gunnelles, D. W.; Wolcott, M. P., 1991: Dynamic wettability of wood. Langmuir, 7 (11): 2498-2502. https://doi.org/10.1021/la00059a017

8. Gérardin, P.; Petrič, M.; Petrissans, M.; Lambert, J.; Ehrhrardt J. J., 2007: Evolution of wood surface free energy after heat treatment. Polymer Degradation and Stability, 92 (4): 653-657.

https://doi.org/10.1016/j.polymdegradstab.2007.01.016

9. Gindl, M.; Sinn, G.; Gindl, W.; Reiterer, A.; Tschegg, S., 2001: A comparison of different methods to calculate the 
surface free energy of wood using contact angle measurements. Colloids and Surfaces A - Physicochemical and Engineering Aspects, 181 (1-3): 279-287. https://doi.org/10.1016/S0927-7757(00)00795-0

10. Gindl, M.; Reiterer, A.; Sinn, G.; Stanzl-Tschegg, S. E., 2004: Effects of surface ageing on wettability, surface chemistry, and adhesion of wood. Holz Als Roh- und Werkstoff, 62 (4): 273-280. https://doi.org/10.1007/s00107-004-0471-4

11. Gonzalez de Cademartori, P. H.; Missio, A. L.; Mattos, B. D.; Gatto, D. A., 2015: Natural weathering performance of three fast-growing Eucalypt woods. Maderas. Ciencia y tecnología, 17 (4): 799-808. https://doi.org/10.4067/S0718-221X2015005000069

12. Hill, C. A. S.; Ramsay, J.; Keating, B.; Laine, K.; Rautkari, L.; Hughes, M.; Constant, B., 2012: The water vapour sorption properties of thermally modified and densified wood. Journal of Materials Science, 47 (7): 3191-3197. https://doi.org/10.1007/s10853-011-6154-8

13. Huang, X.; Kocaefe, D.; Boluk, Y.; Kocaefe, Y.; Pichette, A., 2012: Effect of surface preparation on the wettability of heat-treated jack pine wood surface by different liquids. European Journal of Wood and Wood Products, 70 (5): 711-717. https://doi.org/10.1007/s00107-012-0605-Z

14. Kocaefe, D.; Poncsak, S.; Dor'e, G.; Younsi, R., 2008: Effect of heat treatment on the wettability of white ash and soft maple by water. Holz als Roh- und Werkstoff, 66 (5): 355-361. https://doi.org/10.1007/s00107-008-0233-9

15. Kúdela, J., 2014: Wetting of wood surface by a liquids of a different polarity. Wood Research, 59 (1): 11-24.

16. Li, W., Wang, Ch., Zhang, Y., Jia, Ch., Gao, Ch.; Jin, J., 2014: The Influence of Hot Compression on the Surface Characteristics of Poplar Veneer. BioResources, 9 (2): 2808-2823. https://doi.org/10.15376/biores.9.2.2808-2823

17. Liptákova, E.; Kúdela, J., 1994: Analysis of the wood wetting process. Holzforschung, 48 (2): 139-144. https://doi.org/10.1515/hfsg.1994.48.2.139

18. Liptákova, E.; Kúdela, J.; Bastl, Z.; Spirovová, I., 1995: Influence of mechanical surface treatment of wood on the wetting process. Holzforschung, 49 (4): 369-375. ž https://doi.org/10.1515/hfsg.1995.49.4.369

19. Mantanis, G. I.; Young, R. A.; Rowell, R. M., 1994: Swelling of wood Part 1. Swelling in water. Wood Science and Technology, 28 (2): 119-134. https://doi.org/10.1007/BF00192691

20. Mohan, T.; Kargl, R.; Doliška, A.; Vesel, A.; Köstler, S.; Ribitsch, V.; Stana-Kleinschek, K., 2011: Wettability and surface composition of partly and fully regenerated cellulose thin films from trimethylsilyl cellulose. Journal of Colloid and Interface Science, 358 (2): 604-610. https://doi.org/10.1016/j.jcis.2011.03.022

21. Owens, D. K.; Wendt, R. C., 1969: Estimation of the surface free energy of polymers. Journal of Applied Polymer Science, 13 (8): 1741-1747. https://doi.org/10.1002/app.1969.070130815

22. Pétrissans, M.; Gérardin, P.; Elbakali, D.; Serraj, M., 2003: Wettability of heat-treated wood. Holzforschung, 57 (3): 301-307. https://doi.org/10.1515/HF.2003.045

23. Požgaj, A.; Chowanec, D.; Kurjatko, S.; Babiak, M. 1993: Štruktúra a vlasnosti dreva. Bratislava: Príroda a.s.

24. Richter, H. G.; Dallwitz, M. J., 2000: Commercial timbers: descriptions, illustrations, identification, and information retrieval. In English, French, German, Portuguese, and Spanish. Version: 25th June 2009. http://delta-intkey.com.

25. Rolleri A.; Burgos F.; Aguilera A., 2016: Surface Roughness and Wettability Variation: The effect of Cutting Dis- tance during Milling of Pinus Radiata Wood. Drvna industrija, 67 (3): 223-228.

https://doi.org/10.5552/drind.2016.1531

26. Santoni, I.; Pizzo, B., 2011: Effect of surface conditions related to machining and air exposure on wettability of different Mediterranean wood species. International Journal of Adhesion and Adhesives, 31 (7): 743-753. https://doi.org/10.1016/j.ijadhadh.2011.07.002

27. Sekhar, A. C.; Negi, G. S., 1960: Über die Variationskoeffizienten der mechanischen Eigenschaften des Holzes. Holz als Roh- und Werkstoff, 18 (10): 367-369. https://doi.org/10.1007/BF02605813

28. Shen, Q.; Nylund, J.; Rosenholm, J. B., 1998: Estimation of the surface energy and acid-base properties of wood by means of wetting method. Holzforschung, 52 (5): 521-529. https://doi.org/10.1515/hfsg.1998.52.5.521

29. Wagenführ, R. 2007: Holzatlas. 6., neu bearbeitete und erweiterte Auflage. München: Fachbuchverlag Leipzig im Carl Hanser Verlag.

30. Wålinder, M. E. P.; Johansson, I., 2001: Measurement of wood wettability by the Wilhelmy method. Part 1 . Contamination of Probe Liquids by Extractives. Holzforschung, 55 (1): 21-32. https://doi.org/10.1515/HF.2001.005

31. Wålinder, M. E. P.; Ström, G., 2001: Measurement of wood wettability by the Wilhelmy method. Part 2. Determination of Apparent Contact Angles. Holzforschung, 55 (1): 33-41. https://doi.org/10.1515/HF.2001.006

32. Wolkenhauer, A.; Avramidis, G.; Hauswald, E.; Militz, H.; Viöl, W., 2009: Sanding vs. plasma treatment of aged wood: A comparison with respect to surface energy. International Journal of Adhesion \& Adhesives, 29 (1): 1822. https://doi.org/10.1016/j.ijadhadh.2007.11.001

33. Zhang, H. J.; Gardner, D. J.; Wang, J. Z.; Shi, Q., 1997: Surface tension, adhesive wettability and bondability of artificially weathered CCA treated southern pine. Forest Products Journal, 47 (10): 69-72.

34. *** EN 13556. (2003) Round and sawn timber - Nomenclature of timbers used in Europe. The European Committee for Standardization, Brussels, Belgium.

35. *** EN 1912 (2012) + AC. (2013) Structural timber Strength classes - Assignment of visual grades and species. The European Committee for Standardization, Brussels, Belgium.

36. *** ISO 13061-1. (2014) Physical and mechanical properties of wood - Test methods for small clear wood specimens - Part 1: Determination of moisture content for physical and mechanical tests. International Organization for Standardization, Geneva, Switzerland.

37. *** ISO 13061-2. (2014) Physical and mechanical properties of wood - Test methods for small clear wood specimens - Part 2: Determination of density for physical and mechanical tests. International Organization for Standardization, Geneva, Switzerland.

38. *** ISO 3129. (1979) Wood - Sampling methods and general requirements for physical and mechanical tests. International Organisation for Standardization, Geneva, Switzerland.

\section{Corresponding address:}

Assist. prof. AGNIESZKA LASKOWSKA, Ph.D.

Department of Wood Sciences and Wood Preservation Faculty of Wood Technology

Warsaw University of Life Sciences - SGGW

Nowoursynowska 159 St., 02 - 776 Warsaw, POLAND e-mail: agnieszka_laskowska@sggw.pl 